\title{
Anti-programmed cell death protein 1 (anti-PD1) immunotherapy induced autoimmune polyendocrine syndrome type II (APS-2): a case report and review of the literature
}

\author{
Ashray Gunjur $^{1 *}$ (D), Oliver Klein ${ }^{1,3}$, Damien Kee ${ }^{1,2}$ and Jonathan Cebon ${ }^{1,3}$
}

\begin{abstract}
Background: Autoimmune polyendocrine syndrome type II (APS-2) is a rare constellation of autoimmune hypoadrenalism, thyroid dysfunction and/or type 1 diabetes (T1DM), usually occurring in the 3rd or 4th decades and associated with a human leukocyte antigen (HLA) DR3 or DR4 serotype. We detail the first report of an elderly woman developing the full triad of APS-2 shortly after commencing anti-programmed cell death protein 1 (anti-PD1) immune checkpoint inhibition for unresectable melanoma and review the literature for similar presentations secondary to anti-PD1 axis therapy.

Case: A 78-year-old female with advanced unresectable BRAF wild-type melanoma was treated with pembrolizumab ( $2 \mathrm{mg} / \mathrm{kg} 3$-weekly). Three weeks following the first dose she developed fulminant autoimmune diabetes, with an initially low C-peptide denoting rapid destruction of ß-islet cells. Following stabilisation of her diabetes, two further doses of pembrolizumab was administered. She then represented with symptomatic hypoadrenalism and hypothyroidism, consistent with APS-2. Her HLA class II genotype was HLA-DRB1*04.16 (DR4 serotype), a recognised association with this syndrome. Her melanoma responded rapidly to anti-PD1 therapy, and a complete response (CR) was attained after four doses of pembrolizumab. Treatment was discontinued and her CR is ongoing.

Conclusion: This is the first report of the full triad of APS-2 developing in a genetically susceptible individual at the age of 78 after treatment with an anti-PD1 agent. Although scarcely reported, a literature review of similar reports seems to indicate a predilection for this syndrome in patients with HLA-DR4 serotypes. HLA Class II typing is not routinely recommended, but may provide useful predictive information for patients at risk of poly-endocrinopathy even in patients without a relevant personal or family history. Additional studies are required to determine if such testing would be useful and/or cost effective.
\end{abstract}

Keywords: Immune checkpoint inhibitor, PD1 inhibitor, Pembrolizumab, Poly-endocrinopathy, Diabetes mellitus, Hypoadrenalism, Hypothyroidism

\footnotetext{
* Correspondence: ashray.gunjur@austin.org.au

${ }^{1}$ Department of Medical Oncology, Austin Health, Melbourne, Australia

Full list of author information is available at the end of the article

(c) The Author(s). 2019 Open Access This article is distributed under the terms of the Creative Commons Attribution 4.0 International License (http://creativecommons.org/licenses/by/4.0/), which permits unrestricted use, distribution, and reproduction in any medium, provided you give appropriate credit to the original author(s) and the source, provide a link to the Creative Commons license, and indicate if changes were made. The Creative Commons Public Domain Dedication waiver (http://creativecommons.org/publicdomain/zero/1.0/) applies to the data made available in this article, unless otherwise stated.
} 


\section{Background}

Immune checkpoint inhibitors targeting the programmed cell death protein 1 (PD1) or its ligand (PDL1) have revolutionised the treatment of many malignancies, particularly melanoma, non-small cell lung cancer (NSCLC) and renal cell carcinoma (RCC), however they are not without side effects. These are chiefly inflammatory, often termed "immune related adverse events" (irAEs) and can affect virtually any organ system, including endocrine glands.

Of the anti-PD1-related endocrinopathies thyroiditis is most frequently seen, causing hypothyroidism in approximately $6.0 \%$ and hyperthyroidism in $2.8 \%$ of anti-PD1/PDL1 treated patients (though these data may not capture the proportion of patients transitioning from initial hyperthyroidism to hypothyroidism, which often occurs). Autoimmune diabetes mellitus (DM) or adrenal insufficiency are observed much less frequently; with an allgrade incidence of only 0.4 and $0.69 \%$ respectively [1].

In 1926, Schmidt described two cases of primary adrenal insufficiency coinciding with the occurrence of auto-immune thyroiditis, thereafter eponymously termed "Schmidt syndrome" [2]. Contemporary groups refer to the syndrome as "polyglandular autoimmune syndrome type II" or "autoimmune polyendocrine syndrome type II" (APS-2) with variable definitions, some defining it to occur if any two of three of type 1 diabetes mellitus (T1DM), autoimmune thyroiditis and primary hypoadrenalism occur, while others specifying hypoadrenalism must occur, with at least one of the other two conditions. In either case, APS-2 has a predilection to women; usually develops in the 3rd to 4th decade of life; and is thought to be polygenetic, with mutations in cytotoxic $\mathrm{T}$ lymphocyte-associated antigen 4 (CTLA-4, another immune checkpoint inhibitor (ICI) target) and human leukocyte antigen (HLA) DR3 and DR4 serotypes being known associations $[3,4]$.

Here we report a case of an elderly female who sequentially developed all three features of APS-2 shortly after starting treatment with the anti-PD1 antibody pembrolizumab, with testing confirming a HLA-DRB1*04 genotype (DR4 serotype). Our case description is supplemented by a literature review of PD1/PD-L1 inhibitor associated APS-2.

\section{Case presentation}

A 77-year-old woman of Italian ancestry initially presented with an ulcerated acral melanoma (left heel) in mid-2017 (Breslow depth $2.1 \mathrm{~mm}$, BRAF wild-type). Sentinel lymph node biopsy was negative. She presented 12 months later (mid-2018) with left lower limb lymphoedema and multiple new subcutaneous nodules over that shin. A Fluorodeoxy-glucose (FDG) Positron Emission Tomography (PET) scan demonstrated FDG-avid regional recurrence associated with bulky ipsilateral inguinal and external iliac lymph nodes (Fig. 1). Biopsy of a subcutaneous nodule confirmed in-transit metastatic melanoma (confirming T3bN3M0 disease, stage IIIC by the American Joint Committee on Cancer (AJCC) 8th edition). Co-morbidities included asthma, treated with inhaled corticosteroids and salbutamol, paroxysmal atrial fibrillation, gastro-esophageal reflux disease and hypertension. There was no past or family history of autoimmune or endocrine disease.

Her in-transit and nodal disease was considered unresectable and she was treated with single-agent PD1-inhibitor pembrolizumab ( $2 \mathrm{mg} / \mathrm{kg}$ every 3 weeks), receiving her first dose in July 2018. Baseline blood tests revealed a random glucose of $10.5 \mathrm{mmol} / \mathrm{L}$ (normal range: $4.4-8.9 \mathrm{mmol} / \mathrm{L})(189 \mathrm{mg} / \mathrm{dL})$, sodium of 133 $\mathrm{mmol} / \mathrm{L}$ (normal range: $135-145 \mathrm{mmol} / \mathrm{L}$ ) and thyroid stimulating hormone $(\mathrm{TSH}) 2.34 \mathrm{mU} / \mathrm{L}$ (normal range: $0.27-4.20 \mathrm{mU} / \mathrm{L})$.

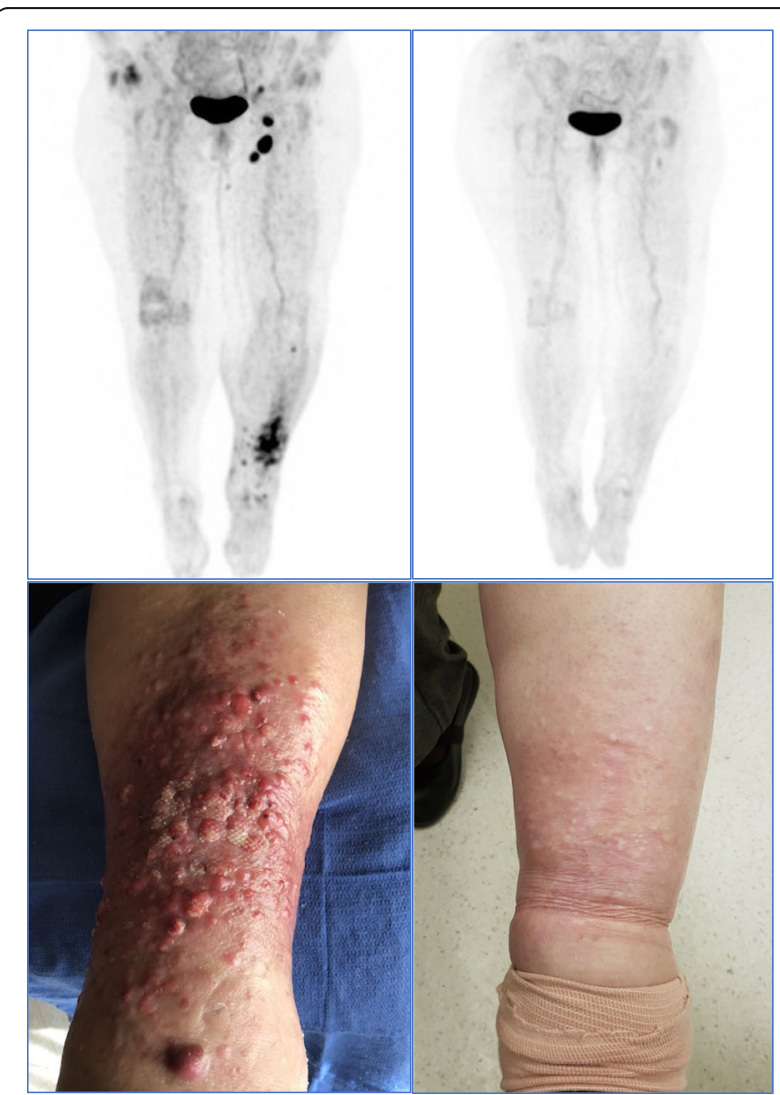

Fig. 1 FDG-PET and Clinical Response. FDG-PET maximum intensity projection in July 2018, prior to pembrolizumab treatment (top left panel) and in April 2019, over 6 months after her fourth and final pembrolizumab treatment (top right), with corresponding clinical photography of the patient's left shin from these time points (bottom left and bottom right respectively). In 2018, lesions over left shin were erythematous non-tender papules and nodules, with biopsy confirming metastatic melanoma 
Three weeks later the patient reported approximately 7 days of worsening malaise, nausea and polyuria. Blood tests revealed a low serum sodium of $120 \mathrm{mmol} / \mathrm{L}$, osmolality of $306 \mathrm{mmol} / \mathrm{kg}$ (normal range: 275-29.5 $\mathrm{mmol} / \mathrm{kg})$, glucose of $44.0 \mathrm{mmol} / \mathrm{L}(792 \mathrm{mg} / \mathrm{dL})$, ketones $1.8 \mathrm{mmol} / \mathrm{L}$ (normal range: $0-0.6 \mathrm{mmol} / \mathrm{L}$ ) and bicarbonate $18 \mathrm{mmol} / \mathrm{L}$ (normal range: $22-30 \mathrm{mmol} / \mathrm{L}$ ). The calculated anion gap was 19.8 , indicating a high-anion gap acidosis. These results were in keeping with fulminant DM with associated pseudohyponatremia.

Emergency management included an insulin infusion and intravenous rehydration, resulting in normalisation of blood glucose and resolution of ketosis. Additional blood tests revealed a mildly elevated HbA1c of $6.9 \%$ (normal range: < 6.5\%), a low C-peptide of $0.22 \mathrm{nmol} / \mathrm{L}$ (normal range: $0.33-$ $1.47 \mathrm{nmol} / \mathrm{L}$ ) and strongly positive auto-antibodies of antiGlutamic Acid Decarboxylase (anti-GAD) > 2000.0 U/ml (normal range: $<5.0 \mathrm{U} / \mathrm{mL}$ ) and anti-islet antibody 2 (antiIA2) $871 \mathrm{U} / \mathrm{mL}$ (normal range: < $15.0 \mathrm{U} / \mathrm{mL}$ ), consistent with T1DM. She was commenced on 40 units of insulin degludec/insulin aspart 70/30 (combination ultra-long and short acting insulin) daily and received her second dose of pembrolizumab on her day of discharge. Three weeks later (early September 2018) the patient had clinically stabilised and had normal thyroid studies (TSH $2.52 \mathrm{mU} / \mathrm{L}$, free T4 $17.28 \mathrm{mU} / \mathrm{L}), 8 \mathrm{am}$ cortisol $(347 \mathrm{nmol} / \mathrm{L}$, normal range: $140-490 \mathrm{nmol} / \mathrm{L})$ and low-normal sodium $(133 \mathrm{mmol} / \mathrm{L})$. She received her third dose of pembrolizumab.

Prior to cycle 4 of pembrolizumab (in late-September 2018) the patient re-presented to the emergency department, now with significant fatigue, functional decline and nausea. The patient's blood pressure was 107/ $68 \mathrm{mmHg}$ (with previous systolic measurements never below $120 \mathrm{mmHg}$ ), heart rate $59 / \mathrm{min}$, respiratory rate $20 /$ min and temperature $35.0^{\circ} \mathrm{C}\left(95.0^{\circ} \mathrm{F}\right)$. Serum sodium was once again noted to be low $(124 \mathrm{mmol} / \mathrm{L})$, this time with a low-normal serum glucose of $4.2 \mathrm{mmol} / \mathrm{L}$ (75.6 $\mathrm{mg} / \mathrm{dL}$ ), thus hyperglycaemia not artifactually contributing to the hyponatraemia. Her potassium was high-nor$\mathrm{mal}$ at $4.9 \mathrm{mmol} / \mathrm{L}$ (normal range $3.5-5.2 \mathrm{mmol} / \mathrm{L}$ ), TSH elevated at $14.2 \mathrm{mU} / \mathrm{L}$ (normal range: $0.27-4.20 \mathrm{mU} / \mathrm{L}$ ), free $\mathrm{T} 4$ borderline-low at $12.0 \mathrm{mU} / \mathrm{L}$ (normal range: 12.0-22.0 mU/L) and other anterior pituitary hormones within normal limits (Fig. 2). Hypocortisolaemia was confirmed $(56 \mathrm{nmol} / \mathrm{L})$ and the patient was commenced on exogenous corticosteroids (initially intravenous hydrocortisone, then transitioned to oral cortisone 20 $\mathrm{mg}$ mane, $10 \mathrm{mg}$ nocte) with rapid clinical improvement. Hypoadrenalism was diagnosed by a short cosyntropin (a synthetic corticotropic agent) test: $250 \mathrm{mcg}$ cosyntropin was administered intravenously and failed to elicit an appropriate cortisol increment after $60 \mathrm{~min}$.

A restaging FDG-PET/CT at this time point demonstrated a near complete response (CR) of the previously FDG-avid in-transit and nodal metastases; no morphological change or metastases to the adrenals; and incidental diffuse FDG uptake in the thyroid consistent with thyroiditis (Fig. 2). Primary hypothyroidism was diagnosed on the basis of a high TSH and borderline low free T4 and replacement therapy with thyroxine was

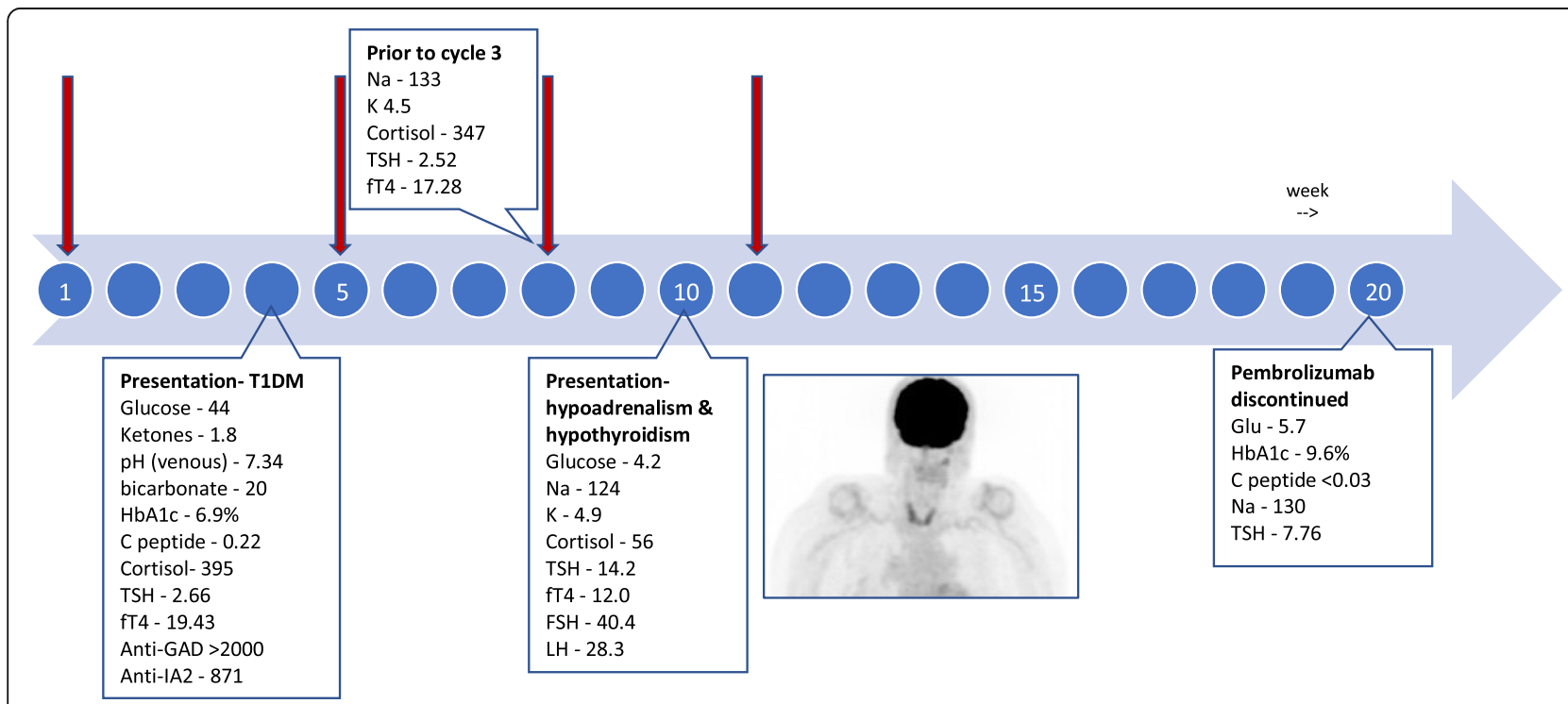

Fig. 2 Time Course. Red arrows indicate pembrolizumab doses, with blue dots indicating passing weeks. FDG-PET maximum intensity projection image was taken at week 10, demonstrating thyroiditis. Laboratory normal reference ranges \& units: Random glucose: $4.4-8.9 \mathrm{mmol} / \mathrm{L}$ (79-160 mg/dL). Ketones: 0-0.6 mmol/L. Sodium (Na): $135-145 \mathrm{mmol} / \mathrm{L}$. Potassium (K): 3.5-5.2 mmol/L. Bicarbonate: $22-30 \mathrm{mmol} / \mathrm{L}$. Cortisol: $140-490 \mathrm{nmol} / \mathrm{L}$. TSH: 0.274.20 mU/L. fT4: 12.0-22.0 mU/L. follicular stimulating hormone (FSH): 25.8-134.8 IU/L (post-menopause). luteinizing hormone (LH): 14.2-52.3 IU/L (postmenopause). HbAlc: <6.5\%. C peptide: $0.33-1.47 \mathrm{nmol} / \mathrm{L}$ 
commenced at $50 \mathrm{mcg}$ per day. Once stabilised and on the day of her discharge she received her fourth and final dose of pembrolizumab.

Three weeks following discharge (in mid-October 2018) repeat thyroid function tests demonstrated persistent hypothyroidism (TSH $40.4 \mathrm{mU} / \mathrm{L}$, free T4 $11.68 \mathrm{mU} /$ $\mathrm{L}$ ) and the patient's thyroxine replacement was increased to $75 \mathrm{mcg}$ per day. A normal MRI of brain, high TSH and the absence of headache helped exclude hypopituitarism as a contributing cause of endocrine dysfunction in this patient. Given the patient's frailty and difficulty attending for infusions, she opted to discontinue further therapy with pembrolizumab.

At the time of writing, almost 1 year after her last dose of pembrolizumab, the patient remains in clinical and radiological remission and is now stable on (likely lifelong) insulin, cortisone and thyroxine replacement. Her $\mathrm{HbA} 1 \mathrm{c}$ is $9.6 \%$ (indicating worsening diabetic control), while her C-peptide is no longer detectable (consistent with destruction of pancreatic $B$-islet glands and no endogenous production of insulin). Patient HLA class II allele typing demonstrated HLA-DRB1*04.16, DQB1*02.05 and DQA1*01.03 allotypes.

\section{Discussion and conclusions}

To our best knowledge we report the first case of the full triad of APS-2: diabetes mellitus, primary hypoadrenalism and hypothyroidism, following monotherapy with a PD1 inhibitor.

Immune-related DM as a consequence of anti-PD1 axis therapy is an uncommon but documented phenomenon, reported in approximately $0.4 \%$ receiving anti-PD1/PD-L1 monotherapy [1]. Our patient's short (1 week) prodrome of symptoms, initially low C-peptide $(0.22 \mathrm{nmol} / \mathrm{L})$ and only modestly elevated initial $\mathrm{HbA} 1 \mathrm{c}$ (6.9\%) point to acute, rapid destruction of $B$-islets in the pancreas. This is consistent with the case details from the largest published series of anti-PD1 therapy induced DM (27 patients), for whom $88 \%$ had low or undetectable C-peptide at diagnosis. In that series, DM developed a median of 20 weeks after starting anti-PD1 therapy (with a wide range 1-228 weeks, indicating a stochastic nature to this event) and interestingly, only $40 \%$ (10 of 25) had one positive T1DM auto-antibody. Those who were 'seropositive' for T1DM (as our patient was) tended to develop it sooner after starting anti-PD1 therapy (at a median of 2.5 versus 13 cycles) [5].

Spontaneous APS-2 is rare, with an estimated prevalence of 1.4-2.0 per 100,000 Caucasians (and a 3:1 predilection for women) [3]. It is thought to be polygenetic, with a large study of 98 German patients with spontaneous APS-2 showing a similar pattern of HLA class II alleles to people with spontaneous T1DM (with significantly higher representation of HLA-DR3 (28.6\%) and DR4 (35.2\%) serotypes than matched health controls (10.6 and $12.6 \%$ respectively) [6]. To review all currently published cases of APS-2 triggered by anti-PD1 therapy we conducted a comprehensive structured MEDLINE ${ }^{\circ}$ search using a combination of Medical Subject Headings $(\mathrm{MeSH})$ terms and keywords (Additional file 1). A secondary search of the bibliographies of all included manuscripts was also undertaken, in total finding 13 relevant cases (Table 1). Of these, only two cases experienced primary hypoadrenalism and none reported all three features of APS-2, making this report unique.

Our patient was 78 years old when she developed APS-2, being the oldest in the identified cases (ranging from 52 to 73 years old). This is striking when considering the average age of developing spontaneous APS-2 is thought to be $30-40$ years old. Including ours, 8 of 14 case reports performed some form of HLA typing, of whom 5 (63\%) were HLA-DR4. This appears somewhat higher than the rate of HLA-DR4 in patients with spontaneous APS-2 (35.2\%), but is similar to that for antiPD1 therapy induced DM ( $76 \%$ in the previously cited case series) [5]. The association of HLA class and susceptibility to irAEs is not well studied, however the well-established relationship between HLA class and spontaneous autoimmunity suggest that this is likely. If so, HLA class II haplotype may serve as a useful biomarker for predicting risk of irAEs - endocrinological and potentially other forms as well, warranting further research.

In parallel to the development of APS-2 our patient had a dramatic, sustained CR of her advanced melanoma after just 4 doses of pembrolizumab. She therefore demonstrated a response to PD1 inhibition that appeared unusually sensitive, both in terms of susceptibility to autoimmune toxicity and therapeutic efficacy. There is an ongoing effort to identify predictive biomarkers for response in patients treated with anti-PD1/PD-L1 agents. These primarily focus on characteristics displayed by the tumor such as the character and localisation of inflammatory cell infiltrates, immune checkpoint expression and gene expression in the tumor microenvironment and $\mathrm{T}$ cell markers [19-21]. Other host factors such as the content and diversity of fecal microbiome also appear to be important and have attracted considerable recent attention [22].

In contrast, relatively little is known about the predictive value of inherited host factors, with only one study (to our best knowledge) exploring the association between HLA haplotypes and treatment response. Through careful analysis of tissue from 1535 advanced cancer patients treated with ICIs, Chowell and colleagues noted significantly extended overall survival (OS) for patients with the HLA-B44 supertype and conversely worse survival with the HLA-B62 supertype. An exploratory 
Table 1 Summary of Case Reports of anti-PD1/PD-L1 induced APS-2 (at least two components)

\begin{tabular}{|c|c|c|c|c|c|c|c|c|c|}
\hline $\begin{array}{l}\text { Author (year } \\
\text { published) }\end{array}$ & Therapy & $\begin{array}{l}\text { Age } \\
\text { (years) }\end{array}$ & Country & Disease & $\begin{array}{l}\text { Timing }{ }^{a} \\
\text { (weeks) }\end{array}$ & Conditions & $\begin{array}{l}\text { auto-Ab } \\
\text { found }\end{array}$ & HLA type & Response \\
\hline Hakami [7] (2019) & pembrolizumab & 52 & Ireland & melanoma & 21 & $\begin{array}{l}\text { hypothyroidism } \\
\text { T1DM }\end{array}$ & & NR & NR \\
\hline Lanzolla [8] (2019) & atezolizumab & 60 & Italy & $\mathrm{NSCLC}$ & 6 & $\begin{array}{l}\text { T1DM } \\
\text { hypoadrenalism }\end{array}$ & $\begin{array}{l}\text { anti-21- } \\
\mathrm{OH}\end{array}$ & $\begin{array}{l}\text { DRB1*04 } \\
\text { DQB1 }{ }^{* 03}\end{array}$ & PD \\
\hline Sakurai [9] (2018) & nivolumab & 68 & Japan & $\mathrm{RCC}$ & 14 & $\begin{array}{l}\text { hypothyroidism } \\
\text { T1DM }\end{array}$ & $\begin{array}{l}\text { anti-TPO } \\
\text { Anti-Tg }\end{array}$ & $\begin{array}{l}\text { DRB1*09: } \\
01 \\
\text { DQB1*03: } \\
03\end{array}$ & NR \\
\hline Gauci [10] (2017) & nivolumab & 73 & France & melanoma & 6 & $\begin{array}{l}\text { hyperthyroidism }{ }^{\text {b }} \\
\text { T1DM }\end{array}$ & $\begin{array}{l}\text { anti-GAD } \\
\text { anti-IA2 } \\
\text { anti-ZnT8 }\end{array}$ & NR & PR \\
\hline $\begin{array}{l}\text { Paepegaey [11] } \\
(2017)\end{array}$ & pembrolizumab & 55 & France & melanoma & 12 & $\begin{array}{l}\text { hypothyroidism } \\
\text { hypoadrenalism }\end{array}$ & $\begin{array}{l}\text { anti-21- } \\
\mathrm{OH}\end{array}$ & NR & NR \\
\hline Li [12] (2017) & nivolumab & 63 & USA & NSCLC & 4 & $\begin{array}{l}\text { T1DM } \\
\text { hypothyroidism }\end{array}$ & $\begin{array}{l}\text { anti-GAD } \\
\text { anti-TPO }\end{array}$ & NR & PD \\
\hline $\begin{array}{l}\text { Alhusseini [13] } \\
\text { (2017) }\end{array}$ & $\begin{array}{l}\text { pembrolizumab + } \\
\text { ipilimumab }\end{array}$ & 65 & USA & NSCLC & 3 & $\begin{array}{l}\text { T1DM } \\
\text { hyperthyroidism }\end{array}$ & $\begin{array}{l}\text { anti-GAD } \\
\text { anti-IA } \\
\text { anti- } \\
\text { insulin } \\
\text { anti-TPO }\end{array}$ & NR & $P R$ \\
\hline Lowe [14] (2016) & nivolumab + ipilimumab & 54 & USA & melanoma & 2 & $\begin{array}{l}\text { hyperthyroidism } \\
\text { T1DM }\end{array}$ & anti-GAD & $\mathrm{DQB1*0602}$ & $C R$ \\
\hline Kong [15] (2016) & pembrolizumab & 68 & Korea & NSCLC & 21 & $\begin{array}{l}\text { T1DM } \\
\text { hyperthyroidism }\end{array}$ & Nil & $\begin{array}{l}\text { DRB1*09: } \\
01 \\
\text { DQB1*03: } \\
03\end{array}$ & PR \\
\hline Hansen [16] (2016) & pembrolizumab & 58 & USA & melanoma & NR & $\begin{array}{l}\text { hypothyroidism } \\
\text { T1DM }\end{array}$ & anti-GAD & NR & PR \\
\hline Mellati [17] (2015) & NR & 66 & & SCC jaw & 7 & $\begin{array}{l}\text { T1DM } \\
\text { hypothyroidism }\end{array}$ & $\begin{array}{l}\text { anti-TPO } \\
\text { anti-GAD }\end{array}$ & $\begin{array}{l}\text { DR3-DQ2 } \\
\text { DR4-DQ8 }\end{array}$ & NR \\
\hline Hughes [18] (2015) & nivolumab + ipilimumab & 55 & USA & melanoma & 20 & $\begin{array}{l}\text { hypothyroidism } \\
\text { T1DM }\end{array}$ & & $\begin{array}{l}\text { A2.1 } \\
\text { DR4 }\end{array}$ & NR \\
\hline Hughes (2015) & pembrolizumab & 64 & USA & melanoma & $<4$ & $\begin{array}{l}\text { hypothyroidism } \\
\text { T1DM }\end{array}$ & & DR4 & NR \\
\hline
\end{tabular}

Abbreviations: auto-Ab auto-antibody, HLA Human leukocyte antigen, T1DM Type 1 diabetes mellitus, NR Not reported, PD Progressive disease, 21-OH 21hydroxylase, anti-TPO Anti-thyroid peroxidase, anti-Tg anti-thyroglobulin, anti-GAD anti-glutamic acid decarboxylase, anti-IA2 anti-islet antibody 2, anti-ZnT8 antizinc transporter $8, P R$ partial response, $C R$ complete response

${ }^{a}$ timing denotes weeks after start of anti-PD1 therapy to onset of APS-2

bauto-immune condition preceded treatment with anti-PD1 axis therapy

analysis found a similar poor association with HLA-DP homozygosity, implying a potential role for HLA class II influencing patient's response to these therapies [23].

As a clinical biomarker, there is also emerging evidence that the development of certain irAEs during antiPD1/PD-L1 axis therapies is associated with treatment response. The most common endocrinological irAE is thyroiditis [1], associated with a significant progressionfree and OS benefit in a retrospective series of NSCLC patients treated with such therapy [7]. Similarly, in another prospective cohort of NSCLC treated with PD1 therapy, those patients experiencing skin toxic effects also had improved OS and PFS. Strikingly, analysis of infiltrating $\mathrm{T}$ cells from matched tumor and skin biopsy samples revealed identical $\mathrm{T}$-cell receptor sequences, indicating the same $\mathrm{T}$ cell clonotype reacting against shared antigens (in tumor and normal tissue). To our knowledge these are the first data to shed light on a mechanism for the association between irAE and anticancer response [24].

Unfortunately, our patient would now likely need lifelong hormone replacement with insulin, corticosteroids and thyroxine, having experienced considerable morbidity from her anti-cancer therapy. This case serves as a reminder to our group and all clinicians to vigilantly monitor for immune related endocrinopathies in patients receiving anti-PD1/PD-L1 inhibitors, even within the first cycle of therapy. As suggested by the Society for Immunotherapy of Cancer Toxicity Management Working Group a pre-treatment baseline TSH, free T4, 8 am 
ACTH, 8 am cortisol, glucose and HbA1c should be considered in all patients prior to immune checkpoint inhibitor therapy. Clinicians should then consider routine monitoring of patients' early morning ACTH and cortisol (every month for 6 months, then every 3 months for 6 months, then every 6 months for 1 year) [25].

\section{Additional file}

Additional file 1: Search strategy developed for the Ovid MEDLINE

database (DOCX $15 \mathrm{~kb})$

\section{Abbreviations}

AJCC: American Joint Committee on Cancer; Anti-GAD: Anti-Glutamic Acid Decarboxylase; Anti-IA2: Anti-islet antibody 2; Anti-PD1: Anti-programmed cell death protein 1; APS-2: Autoimmune polyendocrine syndrome type II; CR: Complete response; CTLA-4: Cytotoxic T lymphocyte-associated antigen 4: DM: Diabetes mellitus; FDG: Fluorodeoxy-glucose; HLA: Human Leukocyte Antigen; ICI: Immune checkpoint inhibitor; irAEs: Immune related adverse events; MeSH: Medical Subject Headings; NSCLC: Non-small cell lung cancer; OS: Overall survival; PD1: Programmed cell death protein 1; PDL1: Programmed death ligand 1; PET: Positron emission tomography; RCC: Renal cell carcinoma; T1DM: Type 1 diabetes mellitus; TSH: Thyroid stimulating hormone

\section{Acknowledgements}

The authors are grateful to the patient and their family for allowing us to share her story. We would like to acknowledge the staff at the Olivia Newton-John Cancer and Wellness Centre for their tireless care for the patient, both as an inpatient and outpatient.

\section{Authors' contributions}

AG: Collected data, wrote manuscript, created figures, incorporated changes (from both internal and external peer-review) and approved final manuscript. OK: critical appraisal, editing and approval of manuscript. DK: critical appraisal, editing and approval of manuscript. JC: developed concept, critical appraisal, editing and approval of manuscript

\section{Funding}

The cost of open-access publication was funded by Ludwig Cancer Research (the Olivia Newton-John Cancer Research Institute).

\section{Availability of data and materials}

Not applicable.

\section{Ethics approval and consent to participate}

The patient signed informed consent to participate in the "Biomarkers in Cancers" study (approved by the Austin Health human research ethics committee) which involves consent for research blood tests including HLA testing.

\section{Consent for publication}

The patient has signed the consent form for the full publication of this case report (available on request)

\section{Competing interests}

The authors declare they have no competing interests.

\section{Author details}

'Department of Medical Oncology, Austin Health, Melbourne, Australia. ${ }^{2}$ Department of Medicine, University of Melbourne, Melbourne, Australia. ${ }^{3}$ Olivia Newton-John Cancer Research Institute, School of Cancer Medicine, La Trobe University, Melbourne, Australia.
Received: 30 May 2019 Accepted: 21 August 2019

Published online: 05 September 2019

\section{References}

1. Wang Y, Zhou S, Yang F, et al. Treatment-Related Adverse Events of PD-1 and PD-L1 Inhibitors in Clinical Trials: A Systematic Review and Metaanalysis. JAMA Oncol. 2019;5(7):1008-1019.

2. Schmidt MB. Eine biglandulare Erkrankung (Nebennieren und Schilddruse bei Morbus Addisonni). Dtsch Pathol Ges. 1926;21:212-21.

3. Betterle C, Dal Pra C, Mantero F, Zanchetta R. Autoimmune adrenal insufficiency and autoimmune Polyendocrine syndromes: autoantibodies, autoantigens, and their applicability in diagnosis and disease prediction. Endocr Rev. 2002;23(3):327-64.

4. Husebye ES, Anderson MS, Kämpe O. Autoimmune Polyendocrine Syndromes. N Engl J Med. 2018;378(12):1132-41.

5. Stamatouli AM, Quandt Z, Perdigoto AL, Clark PL, Kluger H, Weiss SA, et al. Collateral damage: insulin-dependent diabetes induced with checkpoint inhibitors. Diabetes. 2018;67(8):1471-80.

6. Weinstock C, Matheis N, Barkia S, Haager M-C, Janson A, Marković A, et al. Autoimmune polyglandular syndrome type 2 shows the same HLA class II pattern as type 1 diabetest. Tissue Antigens. 2011;77(4):317-24.

7. Kim HI, Kim M, Lee S-H, Park SY, Kim YN, Kim H, et al. Development of thyroid dysfunction is associated with clinical response to PD-1 blockade treatment in patients with advanced non-small cell lung cancer. Oncolmmunology. 2018;7(1):e1375642.

8. Lanzolla G, Coppelli A, Cosottini M, Del Prato S, Marcocci C, Lupi I. Immune checkpoint blockade anti-PD-L1 as a trigger for autoimmune Polyendocrine syndrome. J Endocr Soc. 2019 Feb 1;3(2):496-503.

9. Sakurai K, Niitsuma S, Sato R, Takahashi K, Arihara Z. Painless thyroiditis and fulminant type 1 diabetes mellitus in a patient treated with an immune checkpoint inhibitor, Nivolumab. Tohoku J Exp Med. 2018;244(1):33-40.

10. Gauci M-L, Laly P, Vidal-Trecan T, Baroudjian B, Gottlieb J, Madjlessi-Ezra N, et al. Autoimmune diabetes induced by PD-1 inhibitor-retrospective analysis and pathogenesis: a case report and literature review. Cancer Immunol Immunother. 2017:66(11):1399-410.

11. Paepegaey A-C, Lheure C, Ratour C, Lethielleux G, Clerc J, Bertherat J, et al. Polyendocrinopathy resulting from Pembrolizumab in a patient with a malignant melanoma. J Endocr Soc. 2017;1(6):646-9.

12. Li L, Masood A, Bari S, Yavuz S, Grosbach AB. Autoimmune diabetes and thyroiditis complicating treatment with Nivolumab. Case Rep Oncol. 2017:10(1):230-4.

13. Alhusseini M, Samantray J. Autoimmune diabetes superimposed on type 2 diabetes in a patient initiated on immunotherapy for lung cancer. Diabetes Metab. 2017:43(1):86-8.

14. Lowe JR, Perry DJ, Salama AKS, Mathews CE, Moss LG, Hanks BA. Genetic risk analysis of a patient with fulminant autoimmune type 1 diabetes mellitus secondary to combination ipilimumab and nivolumab immunotherapy. J Immunother Cancer. 2016;4(1):89.

15. Kong SH, Lee SY, Yang YS, Kim TM, Kwak SH. Anti-programmed cell death 1 therapy triggering diabetic ketoacidosis and fulminant type 1 diabetes. Acta Diabetol. 2016;53(5):853-6.

16. Hansen E, Sahasrabudhe D, Sievert L. A case report of insulindependent diabetes as immune-related toxicity of pembrolizumab: presentation, management and outcome. Cancer Immunol Immunother. 2016;65(6):765-7.

17. Mellati M, Eaton KD, Brooks-Worrell BM, Hagopian WA, Martins R, Palmer JP, et al. Anti-PD-1 and anti-PDL-1 monoclonal antibodies causing type 1 diabetes. Diabetes Care. 2015;38(9):e137-8.

18. Hughes J, Vudattu N, Sznol M, Gettinger S, Kluger H, Lupsa B, et al. Precipitation of autoimmune diabetes with anti-PD-1 immunotherapy. Diabetes Care. 2015:38(4):e55-7.

19. Tumeh PC, Harview CL, Yearley JH, Shintaku IP, Taylor EJM, Robert L, et al. PD-1 blockade induces responses by inhibiting adaptive immune resistance. Nature. 2014;515(7528):568-71.

20. Hugo W, Zaretsky JM, Sun L, Song C, Moreno BH, Hu-Lieskovan S, et al. Genomic and transcriptomic features of response to anti-PD-1 therapy in metastatic melanoma. Cell. 2016:165(1):35-44.

21. Sade-Feldman M, Yizhak K, Bjorgaard SL, Ray JP, de Boer CG, Jenkins RW, et al. Defining $T$ cell states associated with response to checkpoint immunotherapy in melanoma. Cell. 2018;175(4):998-1013.e20. 
22. Wang Y, Wiesnoski DH, Helmink BA, Gopalakrishnan V, Choi K, DuPont HL, et al. Fecal microbiota transplantation for refractory immune checkpoint inhibitor-associated colitis. Nat Med. 2018;24(12):1804.

23. Chowell D, Morris LGT, Grigg CM, Weber JK, Samstein RM, Makarov V, et al. Patient HLA class I genotype influences cancer response to checkpoint blockade immunotherapy. Science. 2018;359(6375):582-7.

24. Berner F, Bomze D, Diem S, et al. Association of Checkpoint InhibitorInduced Toxic Effects With Shared Cancer and Tissue Antigens in NonSmall Cell Lung Cancer. JAMA Oncol. 2019;5(7):1043-1047.

25. Puzanov I, Diab A, Abdallah K, Bingham CO, Brogdon C, Dadu R, et al. Managing toxicities associated with immune checkpoint inhibitors: consensus recommendations from the Society for Immunotherapy of Cancer (SITC) toxicity management working group. J Immunother Cancer. 2017:5(1):95

\section{Publisher's Note}

Springer Nature remains neutral with regard to jurisdictional claims in published maps and institutional affiliations.

Ready to submit your research? Choose BMC and benefit from:

- fast, convenient online submission

- thorough peer review by experienced researchers in your field

- rapid publication on acceptance

- support for research data, including large and complex data types

- gold Open Access which fosters wider collaboration and increased citations

- maximum visibility for your research: over $100 \mathrm{M}$ website views per year

At BMC, research is always in progress.

Learn more biomedcentral.com/submissions 